\title{
Stock Price Mean Reversion to Fundamentals and Long-Run Return Predictability in the Tunisian Stock Market
}

\author{
Ramzi Boussaidi ${ }^{1} \&$ Marouan Kouki ${ }^{2}$ \\ ${ }^{1}$ Faculty of Law, Economics and Management of Jendouba, Tunisia \\ ${ }^{2}$ Faculty of Economics and Management of Tunis, Tunisia \\ Correspondence: Marouan Kouki, Faculty of Economics and Management of Tunis, Tunisia. E-mail: \\ koukimarouan@yahoo.fr
}

Received: May 19, 2015

Accepted: June 11, $2015 \quad$ Online Published: July 22, 2015

doi:10.5539/ijbm.v10n8p183

URL: http://dx.doi.org/10.5539/ijbm.v10n8p183

\begin{abstract}
The purpose of this paper is to examine the mean reversion hypothesis in the Tunisian stock market using two methods: We use a cointegration test technique between stock prices and fundamental value and we estimate the model of Chiang et al. (1995) developed to detect a potential mean reversion of stock prices to fundamental. Our results indicate that although stock prices diverge away from their fundamental value proxied by dividends or earnings, there is an error correction mechanism which adjusts stock prices to revert back to their fundamental value. Evidence also shows that mean reversion supports the predictability of stock returns by the dividend to price and the price to earnings ratios.
\end{abstract}

Keywords: Mean reversion, cointegration, efficient market, return predictability

\section{Introduction}

Financial academics and practitioners are usually concerned about the fundamental question whether the past stock price can predict the future stock price. This idea which seems to go back to the work of Bachelier (1900) reappears later with Fama (1965) who concluded that the stock price variations are independent and follow a random walk. Therefore, the market is described to be efficient. A further development of this concept was given by Fama $(1970,1991)$. However, since the eighties, several theoretical and empirical works have shown that the markets are not as efficient as we thought. The efficient market hypothesis, which has long dominated the financial literature, has begun to be rejected after showing that we can partially predict future performance of stocks from their past performance.

Motivated by the work of Kahneman and Tversky (1982) on cognitive psychology, Shiller (1981) on the excessive market volatility and Basu (1977) on the price to earnings ratio anomaly, De Bondt and Thaler (1985) were the first to document a long-run-return reversal indicating a mean reversion in the US market. These authors interpret their results as an over-reaction of the market to the new information. Later, based on the work of Summers (1986), Fama and French (1988a) mathematically show that the mean reversion of the stationary component of stock prices causes a negative long-run return autocorrelation. The long-run reversal of past performance is a phenomenon which corrects the deviation between stock prices and their fundamental values. Such a corrective movement implies the existence of a cointegrating relationship between stock prices and fundamental values, and also reflects an error correction mechanism which adjusts the variations in stock prices towards fundamentals.

This relationship was initially pioneered by Campbell and Shiller (1987) who developed the present value model relating the stock price and its fundamental value measured by dividends. This model implies that stock prices are fundamentally determined by a discounted value of its expected future dividends. To check the validity of the model, the authors have shown that there should exist a stationary linear combination between the stock prices and the dividends, and therefore, a cointegration between the two variables even though their processes are not stationary. Using a different approach, Chiang, Liu and Okunev (1995) have modelled the fundamental value of a stock as a stochastic process and developed an interesting model which links the stock price to the fundamental value and permit to clearly detect the presence of mean reversion. The mean reversion hypothesis implies that future returns can be predicted not only by past returns but also by the dividend to price and the earnings to price 
ratios.

This paper is organized as follows: section 2 briefly reviews the literature, section 3 presents the data and methodology, section 4 examines the empirical tests. The conclusion is in the final section.

\section{Literature Review}

The traditional approach to study the stock price mean reversion was mainly based on cointegration tests between the stock price and the fundamental value or the stationarity tests of the dividend yield. Nasseh and Strauss (2004) applied a cointegration test on panel data between stock price and dividend of a sample of 84 U.S. firms over the period 1979 -1999. They revealed a long-term relationship between the two variables. This result was confirmed when cointegration test was performed for individual firms, indicating, for example with the Johansen test, that most of the firms (55 firms out of 84) show a cointegrating relationship between stock price and fundamental value. Using a similar approach but with time series data, Chen, Kim and Chen (2007) found that the Taiwanese market index does not show a mean reversion towards its fundamental values measured by the DPS or EPS over the period 1995-2004. However, they found a cointegration between the stock price index of only 2 out of 7 sectors (hospitality and building) and EPS. Other empirical studies failed to detect a stock price mean reversion using conventional tests of stationarity and cointegration applied in a linear framework. They suggest that this hypothesis should be examined in a non-linear framework. For example, Coakley and Fuertes (2006) used a non linear threshold autoregressive (TAR) model to study the dynamics of the Price to Earnings and Price to Dividend series of the Standard \& Poor U.S. index over the period 1871-2001. They found that both series show a short-run continuation on a bull market explained by the effect of the investor sentiment and a significant mean reversion towards long run equilibrium. Kapetanios, Shin and Snell (2006) used a non linear Exponential Smooth Transition Autoregressive error correction model (ESTAR-ECM) and found evidence of mean reversion of monthly stock price towards dividends for 7 out of 11 international markets over the period 1974-2002. Similar evidence of non-linear mean reversion is given by McMillan (2007, 2009).

Motivated by the work of De Bondt and Thaler (1985), Chiang et al. (1995) developed a model of stock price mean reversion towards its fundamental value described by a stochastic process. They estimated their model on annual US data of the standard and poor's index covering the period 1871-1986 and found a significant mean reversion for 1, 2, 3, 4 and 10 year horizon investment. This mean reversion is justified by an average speed of adjustment of $14 \%$ when the fundamental value is measured by earnings and $56 \%$ when measured by dividends. Balvers, Wu and Gilliland (2000) have shown that we can test the mean reversion by using either stock indexes relative to a benchmark index such as the world stock index (MSCI) or any other index. Using annual data of 18 international stock market indexes covering the period 1969-1996, they found a mean reversion justified by a significant reversal rate of $18.2 \%$ and $20.2 \%$ when the benchmark index is respectively the world and the stock index of the U.S. Recently, Akarim and Sevim (2013) replicated the methodology of Balvers et al. (2000) to test the validity of the hypothesis of mean reversion of 18 emerging markets for the period 1995-2010. They found that this hypothesis is valid and that the speed of mean reversion varies between 30 and 38 months.

The present value model of Campbell and Shiller (1987) not only links prices to dividends but also suggests that expected stock returns can be predicted by the dividend yield. Fama and French (1988b) have regressed the returns of all the stocks listed on the NYSE during the period 1927-1986 on the dividend yield and found that this ratio, measured either by $\mathrm{D}_{t} / \mathrm{P}_{t}$ or $\mathrm{D}_{\mathrm{t}} / \mathrm{P}_{\mathrm{t}-1}$, has a forecasting power of the nominal and real future returns that increases with the investment horizon. Campbell and Shiller (1988), confirming the results of Fama and French (1988b), found that each of the log dividend-price ratio and the log earnings-price ratio have a significant predictive power of the returns. Kanas (2005) noticed that the log dividend to price ratio has a predictive power of monthly stock returns in four developed markets (the United States, the United Kingdom, Japan and Germany) over the period 1978-2002. Recently, Park (2010) showed that the predictive power of the D/P ratio depends on the persistence of this ratio over the full sample period.

\section{Data and Methodology}

The purpose of this empirical investigation is to examine the mean reversion hypothesis through two methods: First, we use a cointegration test between stock prices and fundamental value. Second, we estimate the model of Chiang et al. (1995) developed to detect a potential mean reversion of stock prices to fundamental.

\subsection{Sample Description}

The data used in this study are annual stock prices (end of the year prices), dividend per share, earnings, and number of shares of all firms listed on the Tunis Stock Exchange for the period 1971 to 2013. We consider all firms for which these data are simultaneously available. Their number has grown from 8 in 1971 to 48 in 2013. 
This allows our indexes to faithfully reproduce almost the performance of the whole market. Given that the Tunisian stock market was reorganized in 1991 and that it has suffered a long-lived stagnation beforehand, results from the full sample period 1971-2013 may be biased by the pre 1991 sub-period market conditions. We, then, consider the 1991-2013 sub-period to check for robustness

\subsection{Measurement of Variables}

The vast majority of the empirical studies on mean reversion use index data on prices, dividends and earnings. It is, therefore, appropriate in this study to construct three indexes reflecting the evolution of the three variables on the Tunisian stock market. The price index is the value weighted price of the firms composing our sample; the dividend index is the value weighted dividend per share; and the earnings index is the value weighted earnings per share. Earnings per share are obtained by dividing annual earnings by the number of shares outstanding at the end of the year.

The first question that should be asked is whether the variables will be used in level or in logarithm. The background of the presence of a cointegration between stock prices and fundamentals is the present value model of Campbell and Shiller (1987). To validate this model in presence of a constant discount rate (constant return), there should be a cointegration between the variables in level whereas in the presence of time-varying discount rate (or expected returns), cointegration should be checked on variables expressed in logarithm. And since this second hypothesis is strongly supported by empirical studies, we express stock price, dividend per share and earnings per share in logarithms as suggested in Bohl and Siklos (2004), Kanas (2005) and McMillan (2007, 2009).

The return form year $t$ to $t+1$ is given by the following equation:

$$
r_{t+1}=\log \left(\frac{P_{t+1}+D_{t+1}}{P_{t}}\right)=\log \left(P_{t+1}+D_{t+1}\right)-\log \left(P_{t}\right)
$$

The return on the portfolio held for $t$ to $t+h$, where $h$ is the investment horizon, is calculated, as suggested by Campbell and Shiller (1988), as follows:

$$
R_{h t}=\sum_{j=0}^{h-1} R_{l, t+j}
$$

\subsection{The Model to Be Tested}

\subsubsection{Detecting Mean Reversion through a Cointegration Test}

The theoretical background necessary to justify the usage of the cointegration technique between stock price and fundamental value is the present value model developed by Campbell and Shiller (1987) and revisited by Campbell, Lo and MacKinlay (1997). Such model implies a stationary linear and nonlinear combination of stock prices and dividends that involves a constant and a time varying discount rate respectively. They started from supposing that the expected stock return is constant and find that the stock price can be expressed as the expected present value of future dividends out to the infinite future, discounted at that constant rate $\mathrm{R}$ as follows:

$$
P_{t}=F_{t}=E_{t}\left(\sum_{i=1}^{\infty}\left(\frac{1}{1+R}\right)^{i} D_{t+i}\right)
$$

If the dividend $D_{t}$ follows a linear process with a unit root, the stock price $P_{t}$ will also follow a linear process with a unit root. In this case, the preceding present value model relates two unit-root processes for $P_{t}$ and $D_{t}$. The authors suggest that it can be transformed to a relation between stationary variables by subtracting a multiple of the dividend from both sides of the preceding equation. They obtained the following equation:

$$
P_{t}-\frac{D_{t}}{R}=\left(\frac{l}{R}\right) E_{t}\left(\sum_{i=l}^{\infty}\left(\frac{1}{1+R}\right)^{i} \Delta D_{t+1+i}\right)
$$

This equation expresses the difference between the stock price and $(1 / \mathrm{R})$ times the dividend as a function of the expectation of the discounted value of future changes in dividends. It implies that if the changes in dividend are stationary, then the expectation of the discounted value of future changes in dividends and, as consequence, the difference between $P_{t}$ and $D_{t} / R$ should also be stationary. In this case, even though both of the dividend and the stock price processes are nonstationary, there should exist a stationary linear combination of prices and dividends indicating that they are cointegrated. As noted above, the preceding equation was derived assuming that the 
expected stock returns are constant. However, such an assumption contradicts the empirical evidence of stock return predictability. When we take into consideration that the stock returns are time-varying, the relation between prices and returns becomes nonlinear, which somehow complicates the preceding analyses and makes working with present-value relations more difficult. To remedy for this problem, the authors proposed a loglinear approximation:

$$
r_{t+1}=p_{t+1}-p_{t}+\log \left(1+e^{d_{t+1}-p_{t+1}}\right)
$$

Where lowercase letters denote logs of the variables. The nonlinearity in this equation is due to the last term on the right-hand side which is a nonlinear function of the log dividend-price ratio. Using a first order Taylor expansion, the last equation can be transformed in the following linear equation:

$$
r_{t+1} \approx k+\rho p_{t+1}+(1-\rho) d_{t+1}-p_{t}
$$

Where $\rho$ and $k$ are parameters of linearization. Solving forward, imposing the condition $\lim _{j \rightarrow \infty} \rho^{j} p_{t+j}=0$ to rule out the explosive behavior caused by rational bubbles, and taking expectations of the obtained equation, the authors obtain the currently well-known and widely-used log-linear approximation of the present value model in presence of time-varying discount rate:

$$
p_{t}=\frac{k}{1-\rho}+E_{t}\left[\sum_{j=0}^{\infty} \rho^{j}\left[(1-\rho) d_{t+1+j}-r_{t+1+j}\right]\right]
$$

Following the authors, the last equation can be written in terms of $\log$ dividend-price ratio rather than the $\log$ stock price as follows:

$$
d_{t}-p_{t}=-\frac{k}{1-\rho}+E_{t}\left[\sum_{j=0}^{\infty} \rho^{j}\left[-\Delta d_{t+1+j}+r_{t+1+j}\right]\right]
$$

The analysis of the cointegrating relationship between stock price and fundamental value is essentially based on this equation. In fact, it implies that if the change in dividends and the discount rate are stationary, then the log dividend-price will also be stationary and, as a consequence the log dividends and log prices are cointegrated with a cointegrating vector $[1,-1]$. To econometrically analyze this equation, Campbell, Lo, and MacKinlay (1997) underlined that there is no need to estimate the unknown parameters; we should rather test the stationarity of the log dividend-price ratio or the cointegration between stock prices and dividends. Evidence of cointegration between the two variables would imply that the mean reversion hypothesis holds. Otherwise, the mean reversion hypothesis is rejected. To examine this hypothesis, we use the Johansen (1991) tests. If we find a cointegration between the two variables, we estimate the Vector Error Correction Model (VECM) between these two variables and focus on the regression of the change in stock price on the lagged change in stock prices, the lagged change in fundamental (dividends) and the error correction term:

$$
\Delta p_{t}=\alpha+\sum_{t=1}^{k} \beta \Delta p_{t-j}+\sum_{t=1}^{k} \theta \Delta f_{t-j}+\gamma e c m_{t-1}+\varepsilon_{t}
$$

A significant negative coefficient of the error correction term $\gamma$ supports the existence of an error correction mechanism in the market that adjusts stock prices to revert back to their fundamental value. The basic theoretical framework for the analyses of the cointegration between stock prices and fundamentals is the present value model which is primary based on dividends, but not on earnings, as a proxy for the fundamental value. Then, using earnings as a fundamental value in this framework should be carefully considered since it has not got a theoretical background like the dividends. In this case, evidence of cointegration between stock prices and earnings will be a further support for the mean reversion hypothesis. Otherwise, it will not necessarily indicate a rejection of the mean reversion hypothesis.

\subsubsection{Return Predictability and Mean Reversion Phenomenon}

There's still much to learn from the preceding fabulous equation of Campbell, Lo and MacKinlay (1997). This 
time, it tells us about the stock return predictability. Two interesting properties can be deduced from this equation:

First, it states that if future returns are expected to be high, then the current prices will be low and the log dividend-price ratio will be high. In this case, the log dividend-price ratio $\left(\mathrm{d}_{\mathrm{t}}-\mathrm{p}_{\mathrm{t}}\right)$ will be a good proxy to forecast future stock returns provided that the expectations of future dividend growth rate are not too variable. Obviously, this equation shows that dividend-price ratio could also predict the future dividend growth. However, the authors assume that even though a small predictable component in the future dividend growth exists, it can be neglected in the forecasting equation given that the variance of the expected dividend growth is considerably low compared to the variance in expected returns. Such a view was supported by Cochrane (2001) who shows that the dividend-price ratio has no forecasting power of the dividend growth. Motivated by these arguments McMillan and Speight (2006) and McMillan (2009) underlined that the possibility of the prediction of the dividend growth by the log dividend to price ratio can be excluded and propose, as in Campbell, Lo and MacKinlay (1997), the following forecasting equation:

$$
r_{t+k}=\alpha+\beta\left(d_{t}-p_{t}\right)+\varepsilon_{t+k t}
$$

Second, because the expectations of the right-hand side of the equation are of a discounted value of all returns into the infinite future, Campbell, Lo, and MacKinlay (1997) underlined that the log dividend yield may represent a better proxy for expectations of long-run returns than for expectations of short-run returns. This may make the forecasting power of returns by the dividend yield increases as the investment horizon increases. Empirically, we expect that the coefficient of determination $\mathrm{R}^{2}$ increases with the return horizon. In the short term, the ratio D/P loses its predictive ability. Bali, Demirtas, and Levy (2008), for example, show that for horizons ranging from 1 to 12 months the coefficient associated with this ratio in the regression of monthly returns in excess of the various US stock indexes for the period 1962-2005 is positive but not statistically significant. Fama and French (1988b) explained the improvement in the predictive power of the dividend yield in the long run by the cumulative effect of the coefficient associated with this ratio in the return regression for shorter horizons. Indeed, for a long-run investment horizon $\mathrm{T}$ this cumulative effect is represented by the sum of the coefficients corresponding to the regression of $r(t, t+1), \ldots, r(t+T-1, t+T)$ on $D / P$. This predictability is perfectly related to the mean reversion phenomenon. To explain this we refer back to the analyses advanced by Fama and French (1988b).

When prices are irrationally below their fundamental value proxied, for example, by dividends, such as the dividend to price ratio is high, the expected future returns will be high because the prices will rebound later and return to their fundamental value. In other words, a high dividend to price ratio indicates high future returns. However, when prices are above their fundamental value indicating a low dividend to price ratio, future returns will be low since the stock price will decrease in order to regain their equilibrium level. Thus, a low dividend yield ratio indicates future low returns. Such analysis matches with the preceding one derived from Campbell, MacKinlay and Shiller (1997).

\subsubsection{Detecting Mean Reversion through the Chiang, Liu and Okunev (1995) Model}

The mean reversion hypothesis implies that when the stock price is above its fundamental value inducing a negative difference between the fundamental value and the stock price, the stock price should decrease to revert back towards its fundamental value in the subsequent period which means that the expected change in stock price should be negative. Similarly, when the stock price is below the fundamental value inducing a positive difference between the fundamental value and the stock price, the stock price should increase to revert back towards its fundamental value inducing then a positive expected change in the stock price. To model such behavior, Chiang et al. (1995) assume that the instantaneous change in the stock price is dependent upon the difference between the fundamental value and the stock price as described by the following process:

$$
d P(t)=\beta[F(t)-P(t)] d t+\delta d z(t)
$$

Where $d P(t)$ is the instantaneous change in the stock price, $F(t)$ is the fundamental value of the stock, $P(t)$ is the stock price, $\beta$ is the speed of adjustment coefficient, $\delta$ is the standard deviation of $d P(t)$ per unit time, $d z(t)$ is a wiener process with mean zero and unit variance. Equation 11 implies that the extent of mean reversion depends on the difference between the fundamental value and the stock price. In fact, the greater the difference between $F(t)$ and $P(t)$ is, the stronger the restoring force back to equilibrium will be. The speed of adjustment coefficient $\beta$ determines how quickly the stock price reverts back towards its fundamental value. The condition for mean 
reversion to exist is that $\beta$ should be positive. If $\beta=0$ the stock price and its fundamental value are not related, and then equation 11 reduces to a random walk. However, if $\beta$ is negative, then $d P(t)$ will move away from equilibrium and will not be mean reverting. In order to operationalize the process, the authors made a simple assumption that the fundamental value could be described by a geometric Brownian motion as follows:

$$
\frac{d F(t)}{F(t)}=\mu d t+\sigma d w(t)
$$

Where $d F(t)$ is the instantaneous change in the fundamental value of the stock, $\mu$ is the drift term, $\sigma$ is the standard deviation per unit time of $d F(t) / F(t)$, and $d w(t)$ is a wiener process with mean zero and unit variance. After solving for $P(t)$ from equation 11, using integration by parts and discretizing the continuous time process, Chiang et al. (1995) obtain the following equation:

$$
\begin{gathered}
\Delta P(t)=\frac{\Delta F(t)}{K}+\left(1-e^{-\beta \Delta t}\right)\left(\frac{F(t)}{K}-P(t)\right)+e^{-\beta(t+\Delta t)} \int_{t}^{t+\Delta t} e^{\beta S} \delta d z(s) \\
-\frac{e^{-\beta(t+\Delta t)}}{K} \int_{t}^{t+\Delta t} \sigma e^{\beta S} F(s) d w(s)
\end{gathered}
$$

A simple representation of this equation is described by the following regression:

$$
\Delta P(t)=\alpha_{1} \Delta F(t)+\alpha_{2} P(t)+\alpha_{3} F(t)+e_{t}
$$

This equation implies that the change in stock price depends upon the change in fundamental value, the lagged price and the lagged fundamental value. The central coefficient of interest in this model is $\alpha_{2}$ because it is related to the speed of adjustment $\beta$ by the following relation: $\alpha_{2}=e^{-\beta \Delta t}-1$ where $\Delta t$ is the investment horizon. A significant positive estimate of $\beta$ is an evidence of the mean reversion hypothesis.

By dividing equation (14) by $P(t)$ and proxying $F(t)$ by earnings per share, the authors find that the stock return can be expressed in terms of earnings $E(t)$, as in Campbell and Shiller (1988), as follows:

$$
R(t)=\alpha_{0}+\alpha_{1} \frac{\Delta E(t)}{P(t)}+\alpha_{2} \frac{E(t)}{P(t)}+\alpha_{3} \frac{D(t)}{P(t)}+e_{t}
$$

Where $R(t)=\frac{\Delta P(t)+D(t)}{P(t)}$.

However, if the fundamental value is proxied by the dividends per share $D(t)$, the appropriate return regression becomes:

$$
R(t)=\alpha_{0}+\alpha_{1} \frac{\Delta D(t)}{P(t)}+\alpha_{2} \frac{D(t)}{P(t)}+e_{t}
$$

In this case, the regression can be related to the work of Fama and French (1988) underlying the good performance of the dividend yield in forecasting the long-run returns.

\section{Empirical Results}

\subsection{Descriptive Statistics}

Table 1 displays the descriptive statistics of $p$, $d p s$ and eps indexes over the full sample period and the sub-period 1991-2013. For the full sample period, the mean of each of the three variables is $3.122 ;-0.224$ and 0.737 , respectively. The standard deviation of $p$ is 0.598 however it is 0.404 for $d p s$ and 0.206 for eps indicating that stock prices are slightly more volatile than dividends, and earnings seem to be less volatile than dividends. In the sub-period, these variables are less volatile however returns of 1,2 and 3 investment horizon are slightly more volatile than in the full sample period. The Jarque and Béra (1984) test shows that the series tend to be normally distributed given that the probability of $J B$ statistic is higher than the conventional levels of significance. 
Table 1. Descriptive statistics

\begin{tabular}{|c|c|c|c|c|c|c|c|c|c|}
\hline & Mean & Median & Max & Min & Std. Dev. & Skewness & Kurtosis & Jarque-Bera & Probability \\
\hline \multicolumn{10}{|c|}{ Panel A. Full sample period 1971-2013 } \\
\hline$p$ & 3,122 & 3,334 & 4,214 & 2,338 & 0,598 & 0,068 & 1,499 & 4,069 & 0,131 \\
\hline$d p s$ & $-0,224$ & $-0,182$ & 0,563 & $-1,113$ & 0,404 & $-0,061$ & 2,151 & 1,319 & 0,517 \\
\hline eps & 0,737 & 0,767 & 1,17 & 0,25 & 0,206 & $-0,452$ & 3,03 & 1,465 & 0,481 \\
\hline$R_{1}$ & 0,063 & 0,074 & 0,753 & $-0,532$ & 0,247 & 0,33 & 4,102 & 2,885 & 0,236 \\
\hline$R_{2}$ & 0,133 & 0,12 & 0,976 & $-0,784$ & 0,362 & 0,115 & 3,805 & 1,197 & 0,55 \\
\hline$R_{3}$ & 0,205 & 0,201 & 1,04 & $-0,694$ & 0,405 & 0,062 & 3,16 & 0,069 & 0,966 \\
\hline$R_{4}$ & 0,274 & 0,222 & 1,151 & $-0,692$ & 0,427 & 0,159 & 3,08 & 0,174 & 0,917 \\
\hline$R_{5}$ & 0,353 & 0,085 & 3,239 & $-0,441$ & 0,747 & 2,211 & 7,816 & 67,672 & 0,000 \\
\hline \multicolumn{10}{|c|}{ Panel B. Sub-period 1991-2013 } \\
\hline$p$ & 3,63 & 3,601 & 4,214 & 3,288 & 0,263 & 0,519 & 2,283 & 1,526 & 0,466 \\
\hline$d p s$ & 0,099 & 0,132 & 0,563 & $-0,213$ & 0,214 & 0,216 & 2,107 & 0,943 & 0,624 \\
\hline eps & 0,852 & 0,869 & 1,17 & 0,462 & 0,148 & $-0,188$ & 4,084 & 1,262 & 0,532 \\
\hline$R_{1}$ & 0,037 & 0,062 & 0,666 & $-0,532$ & 0,286 & 0,093 & 2,688 & 0,121 & 0,941 \\
\hline$R_{2}$ & 0,089 & 0,115 & 0,976 & $-0,784$ & 0,424 & $-0,094$ & 2,868 & 0,046 & 0,977 \\
\hline$R_{3}$ & 0,142 & 0,259 & 0,945 & $-0,694$ & 0,455 & $-0,281$ & 2,332 & 0,636 & 0,728 \\
\hline$R_{4}$ & 0,171 & 0,255 & 0,802 & $-0,692$ & 0,419 & $-0,65$ & 2,398 & 1,623 & 0,444 \\
\hline$R_{5}$ & 0,125 & 0,103 & 0,976 & $-0,441$ & 0,333 & 0,640 & 3,623 & 1,520 & 0,468 \\
\hline
\end{tabular}

Notes. p, dps and eps are respectively stock price index, dividend per share and earnings per share. All variables are expressed in natural logarithm.

\subsection{Cointegration Analysis}

A precondition for cointegration tests is that all variables should have a unit root. To examine the stationarity of the three series, we use Augmented Dickey-Fuller (Dickey and Fuller, 1981) and, Phillips and Perron (1988) tests. Results are displayed in table 2. The DF and PP tests indicate that for both the full sample period and the sub-period, the stock price, the dividend per share, and the earnings per share in level have a unit root and, therefore, non-stationary. However, they are stationary in first difference indicating that they are integrated of order $1, I(1)$. We proceed next to the examination of the cointegration between $p$ and $d p s$, and $p$ and eps.

Table 2. Unit root tests

\begin{tabular}{|c|c|c|c|c|}
\hline & \multicolumn{2}{|c|}{ Full sample period 1971-2013 } & \multicolumn{2}{|c|}{ Sub-period 1991-2013 } \\
\hline & $\mathrm{ADF}$ & PP & $\mathrm{ADF}$ & PP \\
\hline \multicolumn{5}{|c|}{ Panel A. Variables in level } \\
\hline \multirow[t]{2}{*}{$P$} & -2.330 & -2.369 & -0.144 & -0.052 \\
\hline & $(-4.19 /-3.52)$ & $(-4.19 /-3.52)$ & $(-2.69 /-1.96)$ & $(-2.67 /-1.95)$ \\
\hline \multirow[t]{2}{*}{$D p s$} & -3.160 & -3.162 & -1.712 & -2.159 \\
\hline & $(-4.19 /-3.52)$ & $(-4.19 /-3.52)$ & $(-3.80 /-3.02)$ & $(-3.77 /-3.01)$ \\
\hline \multirow[t]{2}{*}{ Eps } & -2.736 & -0.433 & -0.582 & -0.496 \\
\hline & $(-3.59 /-2.93)$ & $(-2.62 /-1.94)$ & $(-2.67 /-1.95)$ & $(-2.67 /-1.95)$ \\
\hline \multicolumn{5}{|c|}{ Panel B. Variables in first difference } \\
\hline \multirow[t]{2}{*}{$\Delta p$} & $-5.668 * *$ & $-5.608 * *$ & $-4.537602 * *$ & $-3.915^{* *}$ \\
\hline & $(-2.62 /-1.94)$ & $(-2.62 /-1.94)$ & $(-2.68 /-1.95)$ & $(-2.68 /-1.95)$ \\
\hline \multirow[t]{2}{*}{$\Delta d p s$} & $-9.262 * *$ & $-9.830 * *$ & $-4.454 * *$ & $-4.756^{* *}$ \\
\hline & $(-2.62 /-1.94)$ & $(-2.62 /-1.94)$ & $(-3.80 /-3.02)$ & $(-3.78 /-3.01)$ \\
\hline \multirow[t]{2}{*}{ ¿eps } & $-6.683 * *$ & $-6.337 * *$ & $-6.310 * *$ & $-4.245^{* *}$ \\
\hline & $(-2.62 /-1.94)$ & $(-2.62 /-1.94)$ & $(-2.68 /-1.95)$ & $(-2.67 /-1.95)$ \\
\hline
\end{tabular}

Notes. p, dps and eps denote stock price, dividend per share and earnings per share in natural logarithm. $\Delta$ denotes the first difference of the variable. Numbers in parentheses are MacKinnon (1996) critical values associated with each statistic at $1 \%$ level (first number in parentheses) and $5 \%$ level (second number in parentheses). Asterisks **,* denote rejection of the null hypothesis of the presence of a unit root at $1 \%$ and $5 \%$ levels, respectively.

Table 3 summarizes the Johansen (1991) test results of the bivariate cointegration between stock price $p$ and $d p s$ 
(Panel A) and stock price $p$ and eps (Panel B). We assume the presence of a linear trend in the series and a constant in the cointegrating relation. The optimal lag, determined based on the Schwartz criterion is 1 for the full sample period and 2 for the sub-period 1991-2013. For the full sample period, the Johansen statistic associated with the Trace test is greater than the critical value at the $5 \%$ level $(16.02>15.41)$ indicating that the null hypothesis of no cointegrating relation between $p$ and $d p s$ can be rejected. However, the null hypothesis of the existence of at most one cointegrating relation between the two variables cannot be rejected at $5 \%$ level. This result is confirmed by the maximum eigenvalue test statistics. In sum, both trace test and maximum eigenvalue test concur with the conclusion of the existence of one cointegrating relation between stock price and $d p s$. Panel B shows that based on the trace test there exists one cointegrating relation between stock price and eps, a result not supported by the maximum eigenvalue test. This divergence between the two tests may make the cointegration result less robust as in the case of $d p s$. For the sub-period 1991-2013, both tests show that there are two cointegrating relations between $p$ and $d p s$ and between $p$ and eps.

Table 3. Cointegration tests between stock price and fundamental value

\begin{tabular}{|c|c|c|c|c|c|c|c|}
\hline \multicolumn{4}{|c|}{ Full sample period $1971-2013$} & \multicolumn{4}{|c|}{ Sub-period 1991-2013 } \\
\hline \multicolumn{8}{|c|}{ Panel A. Cointegration between $p$ and dps } \\
\hline \multicolumn{2}{|c|}{ Trace test } & \multicolumn{2}{|c|}{ Max-eigenvalue test } & \multicolumn{2}{|c|}{ Trace test } & \multicolumn{2}{|c|}{ Max-eigenvalue test } \\
\hline None & At most 1 & None & At most 1 & None & At most 1 & None & At most 1 \\
\hline $\begin{array}{c}16.02 * \\
(15.41 / 20.04)\end{array}$ & $\begin{array}{c}1.536 \\
(3.76 / 6.65) \\
\end{array}$ & $\begin{array}{c}14.48^{*} \\
(14.07 / 18.63)\end{array}$ & $\begin{array}{c}1.536 \\
(3.76 / 6.65)\end{array}$ & $\begin{array}{c}23.83 * * \\
(15.49 / 19.93)\end{array}$ & $\begin{array}{c}4.524 * \\
(3.84 / 6.63)\end{array}$ & $\begin{array}{c}19.31 * * \\
(14.26 / 18.52)\end{array}$ & $\begin{array}{c}4.524^{*} \\
(3.84 / 6.63)\end{array}$ \\
\hline \multicolumn{8}{|c|}{ Panel B. Cointegration between $p$ and eps } \\
\hline $\begin{array}{c}16.42 * \\
(15.49 / 19.93)\end{array}$ & $\begin{array}{c}2.995 \\
(3.76 / 6.63)\end{array}$ & $\begin{array}{c}13.43 \\
(14.07 / 18.52)\end{array}$ & $\begin{array}{c}2.995 \\
(3.76 / 6.63)\end{array}$ & $\begin{array}{c}21.79 * * \\
(15.49 / 19.93)\end{array}$ & $\begin{array}{c}8.131 * * \\
(3.84 / 6.63)\end{array}$ & $\begin{array}{c}13.66 \\
(14.26 / 18.52)\end{array}$ & $\begin{array}{c}8.131 * * \\
(3.84 / 6.63)\end{array}$ \\
\hline
\end{tabular}

Note. numbers in parentheses are Osterwald-Lenum (1992) critical values for rejection of the null at the $5 \%$ and $1 \%$ levels. Asteriscs **, *, indicate rejection of the null at $1 \%$ and $5 \%$ levels, respectively.

Given that there exists a cointegrating relation between stock prices and each of the two proxies of fundamental value, we estimate the Vector Error Correction Model (VECM) between the two variables. The estimation results of this model are reported in table 4 . We report only the equation corresponding to the regression of stock price variation $\left(\Delta p_{t}\right)$ on the lagged stock price variation $\left(\Delta p_{t-j}\right)$, lagged changes in fundamentals $\left(\Delta f_{t-j}\right)$ and the error correction terms $\left(e c t_{t-1}\right)$.

$$
\Delta p_{t}=\alpha+\sum_{t=1}^{k} \beta \Delta p_{t-j}+\sum_{t=1}^{k} \theta \Delta f_{t-j}+\gamma e c m_{t-1}+\varepsilon_{t}
$$

Table 4. Estimation results of the error correction model

\begin{tabular}{|c|c|c|c|c|}
\hline & \multicolumn{2}{|c|}{ full sample 1971-2013 } & \multicolumn{2}{|c|}{ sub-priod 1991-2013 } \\
\hline & $f=d p s$ & $f=e p s$ & $f=d p s$ & $f=e p s$ \\
\hline \multirow[t]{2}{*}{$c$} & 0.018 & 0.023 & -0.019 & 0.005 \\
\hline & $(0.49)$ & $(0.56)$ & $(-0.37)$ & $(0.09)$ \\
\hline \multirow[t]{2}{*}{$\Delta p(-1)$} & $0.284 *$ & 0.073 & $0.598 * *$ & $0.528^{* *}$ \\
\hline & $(1.70)$ & $(0.04)$ & $(2.59)$ & $(2.41)$ \\
\hline \multirow[t]{2}{*}{$\Delta p(-2)$} & & & 0.077 & 0.073 \\
\hline & & & $(0.30)$ & $(0.29)$ \\
\hline \multirow[t]{2}{*}{$\Delta f(-1)$} & -0.265 & 0.064 & -0.053 & $0.715^{* *}$ \\
\hline & $(-1.35)$ & $(0.20)$ & $(-0.18)$ & $(2.06)$ \\
\hline \multirow[t]{2}{*}{$\Delta f(-2)$} & & & 0.442 & $1.132 * *$ \\
\hline & & & $(1.51)$ & $(2.69)$ \\
\hline \multirow[t]{2}{*}{$\mathrm{ecm}$} & $-0.384 * * *$ & -0.010 & $-1.038 * * *$ & $-0.961 * * *$ \\
\hline & $(-2.94)$ & $(-0.16)$ & $(-3.09)$ & $(-3.22)$ \\
\hline$R^{2}$ & 0.195 & 0.0095 & 0.595 & 0.576 \\
\hline
\end{tabular}

Notes. f denotes fundamental value; $\Delta$, first difference. Figures in parentheses are White (1981) corrected t-statistics. Asterisks $* * *, * * * *$ denote significance at $1 \%, 5 \%$ and $10 \%$ levels, respectively. 
For the full sample period, if the fundamental value is proxied by the dividend per share (dps), the coefficient associated with the error correction term has a negative sign significantly different from zero at $1 \%$ level. This indicates that there is a long-run convergence relationship of stock prices with its fundamental value measured by $d p s$. In other words, although stock prices have diverged away from their fundamental value measured by $d p s$ from time to time, there exists an error correction mechanism which adjusts stock prices to return to their fundamental values in support of the mean reversion hypothesis. This result, also, provides support in favor of the long-run validity of the present value model. We further note that, lagged changes in stock price contribute to the prediction of changes in stock price while changes in $d p s$ do not. The explanatory power of the regression given by $R^{2}$ can reach $19.5 \%$. However, when fundamental value is proxied by earnings per share (eps), the coefficient associated with the error correction term is not significant, although it is negative. Furthermore, none of the other regressors can predict the stock price variation which makes the explanatory power of the model very poor $(0.95 \%)$.

For the sub-period sample, results in the case of dividends are similar to those of the full sample period. However, in the case of earnings they show that the error correction term is negative and significantly different from zero at the $1 \%$ level indicating that stock prices tend to revert back to earnings per share. Unlike dividends, lagged changes in earnings can significantly predict changes in stock price. In comparison with the full sample period, we note that the explanatory power of the error correction model has considerably improved.

\subsection{Estimating the Model of Chiang, Liu and Okunev (1997)}

We start by estimating the regression (13) for different investment horizons varying from 1 year to 5 years if the fundamental value is proxied by earnings per share. To correct for heteroscedasticity, we use the White (1981) technique. The estimation of the model for 2, 3, 4 and 5-year-investment horizons requires overlapping observations which causes a residual autocorrelation. A first essay to estimate the model reported a severe residual autocorrelation for such investment horizons that increases as we lengthen the investment horizon. To remedy for this problem, we used the iterative Cochrane-Orcutt procedure. The obtained results for both the full sample period and the 1991-2013 sub-period are displayed in table 5.

$$
\Delta P(t)=\alpha_{1} \Delta E(t)+\alpha_{2} P(t)+\alpha_{3} E(t)+e_{t}
$$

Table 5. Mean reversion towards earnings

\begin{tabular}{|c|c|c|c|c|c|c|c|c|c|c|c|c|}
\hline \multirow[b]{2}{*}{ horizon } & \multicolumn{6}{|c|}{ Full sample period : 1971-2013 } & \multicolumn{6}{|c|}{ Sub-period : 1991-2013 } \\
\hline & $\alpha_{1}$ & $\alpha_{2}$ & $\alpha_{3}$ & $\beta$ & $D W$ & $R^{2}$ & $\alpha_{1}$ & $\alpha_{2}$ & $\alpha_{3}$ & $\beta$ & $D W$ & $R^{2}$ \\
\hline \multirow[t]{2}{*}{1} & 2,559 & $-0,264$ & 3,615 & 0,307 & 1,867 & 0,136 & 4,392 & $-0,633$ & 10,47 & 1,003 & 1,839 & 0,327 \\
\hline & $(0,62)$ & $(-2,48)$ & $(2,38)$ & & & & $(0,71)$ & $(-3,03)$ & $(2,93)$ & & & \\
\hline \multirow[t]{2}{*}{2} & 6,836 & $-0,496$ & 6,924 & 0,343 & 1,180 & 0,281 & 9,139 & $-1,303$ & 21,89 & NA & 1,925 & 0,670 \\
\hline & $(1,85)$ & $(-3,57)$ & $(3,55)$ & & & & $(2,03)$ & $(-5,87)$ & $(5,47)$ & & & \\
\hline \multirow[t]{2}{*}{3} & 5,353 & $-0,918$ & 11,69 & 0,833 & 1,655 & 0,469 & 9,141 & $-1,099$ & 17,64 & NA & 1,957 & 0,571 \\
\hline & $(1,43)$ & $(-5,48)$ & $(4,42)$ & & & & $(1,65)$ & $(-4,38)$ & $(4,05)$ & & & \\
\hline \multirow[t]{2}{*}{4} & 8,493 & $-0,977$ & 12,23 & 0,946 & 1,933 & 0,450 & 13,11 & $-1,029$ & 16,49 & NA & 1,866 & 0,556 \\
\hline & $(1,95)$ & $(-5,27)$ & $(3,53)$ & & & & $(2,11)$ & $(-4,07)$ & $(3,81)$ & & & \\
\hline \multirow[t]{2}{*}{5} & 7,736 & $-0,522$ & 7,838 & 0,148 & 1,935 & 0,282 & 5,003 & $-0,605$ & 9,835 & 0,186 & 1,959 & 0,338 \\
\hline & $(2,19)$ & $(-3,18)$ & $(2,90)$ & & & & $(0,80)$ & $(-2,63)$ & $(2,45)$ & & & \\
\hline
\end{tabular}

Notes. $\mathrm{P}$ is the stock price; $\mathrm{E}$ is the earnings per Share, $\Delta \mathrm{E}$ is the change in earnings per share. Figures in parentheses are $\mathrm{t}$-statistics. $\mathrm{DW}$ is the Durbin Watson statistic after correcting for residual autocorrelation by the Cochrane-Orcutt procedure. $\mathrm{R}^{2}$ is the coefficient of determination. The estimates of $\beta$ are provided by $\alpha_{2}$, since $\alpha_{2}=\mathrm{e}^{-\beta \Delta t}-1$.

First, we consider the results for the full sample period 1971-2013. For each investment horizon, all the coefficients are significantly different from zero except for the coefficient associated with change in the earnings for one year and three- year investment horizons. Moreover, the explanation power of the model increases with the investment horizon from $13.6 \%$ for 1 year to $46.9 \%$ for 3 years. Even though this explanation power decreases for 5-year investment horizon, it remains approximate to $30 \%$. These results indicate that the change in asset prices significantly depends on the change in earnings, lagged stock prices and lagged earnings, which empirically confirms the performance of the Chiang et al. (1995) model in the Tunisian context. The coefficient $\alpha_{2}$ is highly significant for all the investment horizons. The estimates of the speed of adjustment $\beta$ can be calculated from $\alpha_{2}$ by the formula $\beta=-\log \left(1+\alpha_{2}\right) / \Delta t$ where $\Delta t$ is the investment horizon. On average, 
the speed of adjustment for the five-investment horizon is equal to 0.515 which means that stock prices mean reversion to earnings occurs at a rate of $51.5 \%$ per year.

For the sub-period 1991-2013, the explanatory power of the model for each of the investment horizons is considerably approved especially for one and two years. For example, for 1 year $R^{2}$ increases from $13.6 \%$ for the full sample to $32.7 \%$ for the sub-period. Unlike the full sample period, evidence of mean reversion is only found for 1 and 5 year investment horizon. For the other horizons, the estimate of $\alpha_{2}$ is lower than -1 which makes the term in the $\log$ in the preceding formula negative and then the solution for this formula nonexistent. For one year investment horizon, the stock prices are more strongly mean reverting in the 1991-2013 sub-period than in the full sample period. For 5 year horizon, the speed of adjustment is slightly higher than in the full sample period. For these two horizons, it averages about 59.4\%.

Let's focus now on the mean reversion of stock prices to dividends. This is given by the equation 14 if the fundamental value is proxied by dividend per share. The results are reported in table 6 . For the full sample period, all the variables are significant except for the change in dividend for one-year investment horizon suggesting, as in the previous model, the change in dividends per share, the lagged price and the lagged dividend per share significantly explain the change in stock price. The explanatory power varies from $23.7 \%$ to $61 \%$. Although it is higher as opposed to the earnings case, evidence of mean reversion was only found in 1 and 5 year horizon where $\beta$ is significantly positive. For the sub-period 1991-2013, the mean reversion occurs for 1,4 and 5 year investment horizon averaging about 53.6\%. Compared to the earnings case, this means that on average the stock price reverts back to dividends slightly less quickly than to earnings.

Our main empirical finding of the presence of mean reversion of stock price to fundamental value proxied by earnings or dividends in the Tunisian context is consistent with the work of Chiang et al. (1995) in the American context. Our results differ from those of the authors in that they found mean reversion for all their investment horizons including 1, 2, 3, 4 and 10 years, which is not the case in our work when the fundamental value is proxied by dividends. In sum, these results corroborate the results found based on the cointegration tests supporting the existence of a mean reversion of stock prices to the fundamental value.

$$
\Delta P(t)=\alpha_{1} \Delta D(t)+\alpha_{2} P(t)+\alpha_{3} D(t)+e_{t}
$$

Table 6. Mean reversion towards dividends

\begin{tabular}{|c|c|c|c|c|c|c|c|c|c|c|c|c|}
\hline \multirow[b]{2}{*}{ horizon } & \multicolumn{6}{|c|}{ Full sample period: 1971-2013 } & \multicolumn{6}{|c|}{ Sub-period: 1991-2013 } \\
\hline & $\alpha_{1}$ & $\alpha_{2}$ & $\alpha_{3}$ & $\beta$ & DW & $\mathrm{R}^{2}$ & $\alpha_{1}$ & $\alpha_{2}$ & $\alpha_{3}$ & $\beta$ & DW & $\mathrm{R}^{2}$ \\
\hline 1 & $\begin{array}{l}10,74 \\
(1,40)\end{array}$ & $\begin{array}{l}-0,431 \\
(-3,39)\end{array}$ & $\begin{array}{l}14,02 \\
(3,31)\end{array}$ & 0,564 & 1,798 & 0,237 & $\begin{array}{l}11,33 \\
(0,95)\end{array}$ & $\begin{array}{l}-0,482 \\
(-2,54)\end{array}$ & $\begin{array}{l}16,29 \\
(2,44)\end{array}$ & 0,658 & 1,805 & 0,263 \\
\hline 2 & $\begin{array}{l}16,17 \\
(2,66)\end{array}$ & $\begin{array}{l}-1,152 \\
(-7,64)\end{array}$ & $\begin{array}{l}36,60 \\
(6,28)\end{array}$ & NA & 1,922 & 0,619 & $\begin{array}{l}15,40 \\
(1,70)\end{array}$ & $\begin{array}{l}-1,201 \\
(-5,59)\end{array}$ & $\begin{array}{l}39,95 \\
(4,69)\end{array}$ & NA & 1,795 & 0,652 \\
\hline 3 & $\begin{array}{l}19,60 \\
(2,46)\end{array}$ & $\begin{array}{l}-1,077 \\
(-6,07)\end{array}$ & $\begin{array}{l}33,61 \\
(5,29)\end{array}$ & NA & 1,873 & 0,514 & $\begin{array}{l}17,21 \\
(1,47)\end{array}$ & $\begin{array}{l}-1,121 \\
(-4,45)\end{array}$ & $\begin{array}{l}35,28 \\
(3,86)\end{array}$ & NA & 1,986 & 0,558 \\
\hline 4 & $\begin{array}{l}22,64 \\
(2,85)\end{array}$ & $\begin{array}{l}-1,048 \\
(-5,64)\end{array}$ & $\begin{array}{l}32,53 \\
(4,89)\end{array}$ & NA & 1,708 & 0,490 & $\begin{array}{l}19,53 \\
(1,69)\end{array}$ & $\begin{array}{l}-0,952 \\
(-3,56)\end{array}$ & $\begin{array}{l}31,54 \\
(3,49)\end{array}$ & 0,759 & 1,147 & 0,451 \\
\hline 5 & $\begin{array}{l}17,13 \\
(2,30)\end{array}$ & $\begin{array}{l}-0,586 \\
(-3,54)\end{array}$ & $\begin{array}{l}20,08 \\
(3,23)\end{array}$ & 0,177 & 1,844 & 0,328 & $\begin{array}{l}6,943 \\
(0,70)\end{array}$ & $\begin{array}{l}-0,617 \\
(-3,05)\end{array}$ & $\begin{array}{l}20,70 \\
(2,99)\end{array}$ & 0,192 & 1,876 & 0,404 \\
\hline
\end{tabular}

Note. $\mathrm{D}$ is the Dividend per share; $\Delta \mathrm{D}$ is the change in Dividend per share. For other information see notes under table 5.

\subsection{Long-Run Return Predictability by Fundamentals}

Table 7 presents regression results of multiperiod returns on the log dividend yield (equation 10) for the full sample period 1971-2013 and the sub-period 1991-2013. As expected, the log dividend yield has a positive sign coefficient as predicted by the mean reversion hypothesis. This coefficient is significantly different from zero for all horizons and generally high for the longer ones. Moreover, the forecasting power of this ratio is statistically significant at conventional levels (the probability corresponding to the Fisher stat. is less than 5\%) but it does not generally increase monotonically with the investment horizon although it's important for longer horizon than for one year investment horizon: for example, for the full sample period, $R^{2}$ increases from $16,9 \%$ for 1 year to $35.6 \%$ for 3 years but it decreases to $14.3 \%$ for 5 years. Note that the forecasting power of the dividend yield is more important for the sub-period 1991-2013 than for the whole sample period. For example, for 2-year investment horizon, this ratio explains $64.5 \%$ of the variance in returns for the sub-period and $33.9 \%$ for the full sample 
period. Estimating the forecasting equation with the log earnings-price ratio reports similar results (see table 8).

$$
r_{t}=\alpha+\beta \log (D / P)_{t-1}+\varepsilon_{t}
$$

Table 7. Predicting stock returns by log dividend yield

\begin{tabular}{|c|c|c|c|c|c|c|c|c|c|c|}
\hline \multirow[b]{2}{*}{$\mathrm{h}$} & \multicolumn{5}{|c|}{ Full sample period 1971-2013 } & \multicolumn{5}{|c|}{ Sub-period 1991-2013 } \\
\hline & $\alpha$ & $\beta$ & $\mathrm{R}^{2}$ & DW & $\mathrm{P}(\mathrm{F})$ & $\alpha$ & $\beta$ & $\mathrm{R}^{2}$ & DW & $\mathrm{P}(\mathrm{F})$ \\
\hline 1 & $\begin{array}{c}1.143 * * * \\
(2.96)\end{array}$ & $\begin{array}{c}0.323^{* * *} \\
(2.82)\end{array}$ & $16.9 \%$ & 1.93 & $0.75 \%$ & $\begin{array}{c}1.683^{* *} \\
(2.56)\end{array}$ & $\begin{array}{c}0.467 * * \\
(2.53)\end{array}$ & $25.1 \%$ & 1.91 & $2.06 \%$ \\
\hline 2 & $\begin{array}{c}2.439 * * * \\
(4.57)\end{array}$ & $\begin{array}{c}0.691 * * * \\
(4.41)\end{array}$ & $33.9 \%$ & 1.77 & $0.01 \%$ & $\begin{array}{c}4.207 * * * \\
(5.61)\end{array}$ & $\begin{array}{c}1.176^{* * *} \\
(5.72)\end{array}$ & $64.5 \%$ & 1.66 & $0.00 \%$ \\
\hline 3 & $\begin{array}{c}2.645^{* * *} \\
(4.73)\end{array}$ & $\begin{array}{c}0.740 * * * \\
(4.52)\end{array}$ & $35.6 \%$ & 1.72 & $0.01 \%$ & $\begin{array}{c}3.750 * * * \\
(4.20)\end{array}$ & $\begin{array}{c}1.076^{* * *} \\
(4.31)\end{array}$ & $52.2 \%$ & 2.15 & $0.05 \%$ \\
\hline 4 & $\begin{array}{c}2.586^{* * *} \\
(4.38)\end{array}$ & $\begin{array}{c}0.708^{* * *} \\
(4.11)\end{array}$ & $32.0 \%$ & 1.74 & $0.02 \%$ & $\begin{array}{c}3.175^{* * *} \\
(3.42)\end{array}$ & $\begin{array}{c}0.904 * * * \\
(3.45)\end{array}$ & $42.6 \%$ & 1.61 & $0.33 \%$ \\
\hline 5 & $\begin{array}{c}2.459 * * * \\
(2.59)\end{array}$ & $\begin{array}{c}0.636^{* *} \\
(2.42)\end{array}$ & $14.3 \%$ & 1.81 & $2.09 \%$ & $\begin{array}{c}2.153 * * * \\
(2.88)\end{array}$ & $\begin{array}{c}0.594 * * * \\
(2.78)\end{array}$ & $34.0 \%$ & 1.96 & $1.40 \%$ \\
\hline
\end{tabular}

Note. Figures in parentheses are t-statistics.

To further explore the explanatory power of earnings, we used a moving average of earnings per share as in Campbell and Shiller (1988). Given that our period is not as long as theirs, the moving average is calculated on 5 years. We regress returns on the moving average of log earnings minus log stock price. The results, displayed in table 9, reveal a significant improvement of the predictive power of earnings particularly for 1 and 2 -year horizon. For example, for a one-year horizon, the $R^{2}$ increased from $9.35 \%$ to $43.2 \%$ for the full sample period. For 2 years, it increased from $49.9 \%$ to $60 \%$. For the sub-period, the forecasting power exceeds $50 \%$ for some horizon investment and it can reach $65 \%$. All the other aspects about the coefficient slopes and the forecasting power previously deduced are generally maintained.

$$
r_{t}=\alpha+\beta \log (E / P)_{t-1}+\varepsilon_{t}
$$

\begin{tabular}{|c|c|c|c|c|c|c|c|c|c|c|}
\hline \multicolumn{6}{|c|}{ Full sample period $1971-2013$} & \multicolumn{5}{|c|}{ Sub-period 1991-2013 } \\
\hline $\mathrm{h}$ & $\alpha$ & $\mathrm{B}$ & $\mathrm{R}^{2}$ & DW & $\mathrm{P}(\mathrm{F})$ & $\alpha$ & $\beta$ & $\mathrm{R}^{2}$ & DW & $\mathrm{P}(\mathrm{F})$ \\
\hline 1 & $\begin{array}{c}0.489 * * \\
(2.23)\end{array}$ & $\begin{array}{c}0.179 * * \\
(2.01)\end{array}$ & $9.35 \%$ & 1.93 & $5.19 \%$ & $\begin{array}{c}1.712 * * * \\
(3.15)\end{array}$ & $\begin{array}{c}0.598 * * * \\
(3.11)\end{array}$ & $33.7 \%$ & 1.88 & $0.58 \%$ \\
\hline 2 & $\begin{array}{c}2.779 * * * \\
(4.78)\end{array}$ & $\begin{array}{c}1.045^{* * *} \\
(6.15)\end{array}$ & $49.9 \%$ & 2.03 & $0.00 \%$ & $\begin{array}{c}3.421 * * * \\
(5.56)\end{array}$ & $\begin{array}{c}1.203 * * * \\
(5.55)\end{array}$ & $63.1 \%$ & 1.62 & $0.00 \%$ \\
\hline 3 & $\begin{array}{c}2.549 * * * \\
(4.60)\end{array}$ & $\begin{array}{c}0.981 * * * \\
(5.65)\end{array}$ & $46.3 \%$ & 1.62 & $0.00 \%$ & $\begin{array}{c}2.968 * * * \\
(4.1)\end{array}$ & $\begin{array}{c}1.054 * * * \\
(4.09)\end{array}$ & $49.6 \%$ & 1.57 & $0.08 \%$ \\
\hline 4 & $\begin{array}{c}2.094 * * * \\
(3.78)\end{array}$ & $\begin{array}{c}0.778^{* * *} \\
(3.93)\end{array}$ & $30.0 \%$ & 1.65 & $0.04 \%$ & $\begin{array}{c}2.498 * * * \\
(3.2)\end{array}$ & $\begin{array}{c}0.871 * * * \\
(3.13)\end{array}$ & $38.0 \%$ & 1.57 & $0.64 \%$ \\
\hline 5 & $\begin{array}{l}1.652 * \\
(1.89)\end{array}$ & $\begin{array}{c}0.542 * \\
(1.74) \\
\end{array}$ & $7.95 \%$ & 1.65 & $9.10 \%$ & $\begin{array}{c}1.570 * * \\
(2.24)\end{array}$ & $\begin{array}{c}0.540 * * \\
(2.17)\end{array}$ & $23.8 \%$ & 1.72 & $4.68 \%$ \\
\hline
\end{tabular}

Tableau 8. Predicting stock returns by log earnings-price ratio

Note. Figures in parentheses are t-statistics.

These results corroborate those found by Fama and French (1988b) and Campbell and Shiller (1988) on the US market. Fama and French (1988) found that the dividend yield explains $25 \%$ of the variance in returns. Campbell and Shiller (1988) found that the ratio dividend yield in log explains only $3.9 \%$ of the variance of one-year returns, $11 \%$ for three years and $26.6 \%$ for 10 years. By considering a thirty-year moving average of earnings per share, they found that the explanatory power of the log earning to price ratio is $19.5 \%$ for 3 years and rises to $56.6 \%$ for 10 years. 


$$
r_{t}=\alpha+\beta\left[\left(\log \left(B_{t-1}\right)+\ldots+\log \left(B_{t-5}\right)\right) / 5-\log \left(P_{t-1}\right)\right]+\varepsilon_{t}
$$

Table 9. Predicting stock returns by a moving average of earnings

\begin{tabular}{|c|c|c|c|c|c|c|c|c|c|c|}
\hline \multirow[b]{2}{*}{$\mathrm{h}$} & \multicolumn{5}{|c|}{ Full sample period 1971-2013 } & \multicolumn{5}{|c|}{ Sub-period 1991-2013 } \\
\hline & $\alpha$ & $\beta$ & $\mathrm{R}^{2}$ & DW & $\mathrm{P}(\mathrm{F})$ & $\alpha$ & $\beta$ & $\mathrm{R}^{2}$ & DW & $\mathrm{P}(\mathrm{F})$ \\
\hline \multirow[t]{2}{*}{1} & $2.369 * * *$ & $0.880 * * *$ & $43.2 \%$ & 1.90 & $0.00 \%$ & $2.073 * * *$ & $0.742 * * *$ & $36.7 \%$ & 1.76 & $0.99 \%$ \\
\hline & $(4.19)$ & $(5.16)$ & & & & $(2.95)$ & $(2.95)$ & & & \\
\hline \multirow[t]{2}{*}{2} & 0.148 & $1.264 * * *$ & $60.4 \%$ & 1.74 & $0.00 \%$ & $3.591 * * *$ & $1.271 * * *$ & $65.7 \%$ & 1.78 & $0.01 \%$ \\
\hline & $(0.03)$ & $(7.20)$ & & & & $(5.22)$ & $(5.18)$ & & & \\
\hline \multirow[t]{2}{*}{3} & $2.819 * * *$ & $1.024 * * *$ & $48.3 \%$ & 1.57 & $0.00 \%$ & $3.076^{* * *}$ & $1.063 * * *$ & $55.5 \%$ & 1.76 & $0.14 \%$ \\
\hline & $(4.94)$ & $(5.56)$ & & & & $(4.21)$ & $(4.03)$ & & & \\
\hline \multirow[t]{2}{*}{4} & $3.073 * * *$ & $1.049 * * *$ & $47.9 \%$ & 1.69 & $0.00 \%$ & $3.067 * * *$ & $1.047 * * *$ & $64.4 \%$ & 1.57 & $0.03 \%$ \\
\hline & $(3.91)$ & $(5.42)$ & & & & $(5.11)$ & $(4.85)$ & & & \\
\hline \multirow[t]{2}{*}{5} & $2.810 * * *$ & $0.947 * * *$ & $21.6 \%$ & 1.67 & $0.64 \%$ & $2.087 * * *$ & $0.726 * * *$ & $36.4 \%$ & 1.86 & $1.03 \%$ \\
\hline & $(2.80)$ & $(2.93)$ & & & & $(3.02)$ & (2.93) & & & \\
\hline
\end{tabular}

Note. Figures in parentheses are t-statistics.

Table 10 displays estimation results of the equation 15 of Chiang et al. (1995). For the full sample period, the coefficients associated with the change in earnings and the dividend yield are generally significant at the $1 \%$ and $10 \%$ level respectively except for one year investment horizon where the model is not globally significant $(\mathrm{P}(\mathrm{F})>$ $10 \%$ ), however the one associated to the earnings to price ratio is generally not significant. This indicates that the change in earnings and the dividend yield help to forecast long-run returns. Note that the explanatory power of the model increases with the investment horizon however the regression slopes do not.

$$
R(t)=\alpha_{0}+\alpha_{1} \frac{\Delta E(t)}{P(t)}+\alpha_{2} \frac{E(t)}{P(t)}+\alpha_{3} \frac{D(t)}{P(t)}+e_{t}
$$

\begin{tabular}{|c|c|c|c|c|c|c|c|c|c|c|c|c|c|c|}
\hline \multirow[b]{2}{*}{ horizon } & \multicolumn{7}{|c|}{ Full sample period : 1971-2013 } & \multicolumn{7}{|c|}{ Sub-period : 1991-2013 } \\
\hline & $\alpha_{0}$ & $\alpha_{1}$ & $\alpha_{2}$ & $\alpha_{3}$ & DW & $\mathrm{R}^{2}$ & $\mathrm{P}(\mathrm{F})$ & $\alpha_{0}$ & $\alpha_{1}$ & $\alpha_{2}$ & $\alpha_{3}$ & DW & $\mathrm{R}^{2}$ & $\mathrm{P}(\mathrm{F})$ \\
\hline \multirow[t]{2}{*}{1} & $-0,190$ & 4,665 & $-0,630$ & 9,502 & 1,970 & 0,149 & 0,110 & $-0,560$ & 6,119 & 12,92 & $-5,748$ & 1,916 & 0,276 & 0,131 \\
\hline & $(-1,26)$ & $(1,51)$ & $(-0,47)$ & $(1,75)$ & & & & $(-2,05)$ & $(0,85)$ & $(1,60)$ & $(-0,40)$ & & & \\
\hline \multirow[t]{2}{*}{2} & $-0,583$ & 7,937 & 0,345 & 19,33 & 1,823 & 0,330 & 0,002 & $-1,263$ & 12,77 & 25,07 & $-6,418$ & 2,092 & 0,547 & 0,005 \\
\hline & $(-2,34)$ & $(2,86)$ & $(0,15)$ & $(2,48)$ & & & & $(-3,62)$ & $(2,07)$ & $(2,50)$ & $(-0,36)$ & & & \\
\hline \multirow[t]{2}{*}{3} & $-0,946$ & 6,556 & 10,16 & 4,943 & 2,117 & 0,360 & 0,001 & $-1,103$ & 12,07 & 23,65 & $-9,343$ & 2,046 & 0,481 & 0,017 \\
\hline & $(-2,37)$ & $(2,05)$ & $(2,62)$ & $(0,57)$ & & & & $(-2,89)$ & $(1,86)$ & $(2,28)$ & $(-0,49)$ & & & \\
\hline \multirow[t]{2}{*}{4} & $-0,715$ & 7,518 & 5,096 & 12,73 & 1,910 & 0,451 & 0,000 & $-0,833$ & 7,875 & 16,17 & $-2,257$ & 1,598 & 0,375 & 0,064 \\
\hline & $(-2,28)$ & $(3,05)$ & $(1,65)$ & $(1,76)$ & & & & $(-2,23)$ & $(1,13)$ & $(1,91)$ & $(-0,14)$ & & & \\
\hline \multirow[t]{2}{*}{5} & $-0,504$ & 9,993 & 2,729 & 14,65 & 1,956 & 0,460 & 0,000 & $-0,686$ & 4,780 & 2,826 & 19,283 & 1,734 & 0,450 & 0,034 \\
\hline & $(-1,49)$ & $(4,15)$ & $(0,80)$ & $(1,71)$ & & & & $(-2,53)$ & $(0,96)$ & $(0,46)$ & $(1,72)$ & & & \\
\hline
\end{tabular}

Table 10. Return predictability by earnings

Note. see table 5 .

For the sub-period sample 1991-2013, the variables do not explain the one year investment horizon return. For the rest of the investment horizons, the predictive power of the dividend yield was absorbed by the change in earnings and the earnings to price ratios except for 5 years, which suggests that the earnings dominate the dividends in explaining the variance of the long run returns. However, this explanation power does not increase with the investment horizon given that neither the regression slopes corresponding to the earnings variables nor 
the $R^{2}$ increase with the investment horizons.

$$
R(t)=\alpha_{0}+\alpha_{1} \frac{\Delta D(t)}{P(t)}+\alpha_{2} \frac{D(t)}{P(t)}+e_{t}
$$

Table 11. Return predictability by dividends

\begin{tabular}{|c|c|c|c|c|c|c|c|c|c|c|c|c|}
\hline \multirow[b]{2}{*}{ horizon } & \multicolumn{6}{|c|}{ Full sample period : 1971-2013 } & \multicolumn{6}{|c|}{ Sub-period : 1991-2013 } \\
\hline & $\alpha_{0}$ & $\alpha_{1}$ & $\alpha_{2}$ & DW & $\mathrm{R}^{2}$ & $\mathrm{P}(\mathrm{F})$ & $\alpha_{0}$ & $\alpha_{1}$ & $\alpha_{2}$ & DW & $\mathrm{R}^{2}$ & $\mathrm{P}(\mathrm{F})$ \\
\hline \multirow[t]{2}{*}{1} & $-0,349$ & 9,298 & 11,948 & 1,909 & 0,165 & 0,032 & $-0,431$ & 12,618 & 16,371 & 1,910 & 0,207 & 0,124 \\
\hline & $(-1,99)$ & $(1,72)$ & $(2,64)$ & & & & $(-1,66)$ & $(1,02)$ & $(2,07)$ & & & \\
\hline \multirow[t]{2}{*}{2} & $-0,804$ & 21,687 & 25,033 & 1,828 & 0,348 & 0,000 & $-1,211$ & 17,528 & 42,713 & 2,056 & 0,480 & 0,004 \\
\hline & $(-3,11)$ & $(3,06)$ & $(3,97)$ & & & & $(-3,01)$ & $(1,39)$ & $(3,80)$ & & & \\
\hline \multirow[t]{2}{*}{3} & $-0,836$ & 23,592 & 27,091 & 1,909 & 0,373 & 0,000 & $-0,897$ & 22,420 & 31,652 & 1,967 & 0,342 & 0,035 \\
\hline & $(-3,02)$ & $(3,13)$ & $(4,15)$ & & & & $(-2,20)$ & $(1,36)$ & $(2,68)$ & & & \\
\hline \multirow[t]{2}{*}{4} & $-0,967$ & 18,915 & 31,606 & 1,839 & 0,442 & 0,000 & $-0,777$ & 13,305 & 26,252 & 1,754 & 0,373 & 0,030 \\
\hline & $(-3,19)$ & $(3,06)$ & $(5,19)$ & & & & $(-2,54)$ & $(1,26)$ & $(2,95)$ & & & \\
\hline \multirow[t]{2}{*}{5} & $-0,722$ & 24,750 & 25,479 & 1,631 & 0,435 & 0,000 & $-0,693$ & 9,586 & 23,039 & 1,877 & 0,445 & 0,016 \\
\hline & $(-2,08)$ & $(4,02)$ & $(3,90)$ & & & & $(-2,62)$ & $(1,25)$ & $(3,11)$ & & & \\
\hline
\end{tabular}

Note. Figures in parentheses are t-statistics.

In the dividend model (equation 16), for the full sample period both the change in dividends to price and the dividend yield are highly significant (at $1 \%$ level) for all the investment horizons (Table 11). The forecasting power of the explanatory variables is statistically significant given that the probability corresponding to the Fisher statistic is less than $5 \%$. Besides, as we lengthen the investment horizon the proportion of the return variance explained by these variables increases from $16.5 \%$ for 1 year to $44.2 \%$ for 4 years. We also note that the regression slopes corresponding to the two variables increase with the return horizon. The results suggest that the dividends have a reliable forecasting power of the long run returns in the Tunisian stock market. For the sub-period sample, only the dividend yield explains significantly stock return. In sum, the earnings seem to show a predictive power as important as dividends which makes of them a reliable predictor of future returns and a good proxy for fundamental value. As a consequence, when evaluating stocks performance Tunisian investors should focus not only on dividends but also on earnings.

\section{Conclusion}

We used two methods to examine the hypothesis of mean reversion on the Tunis Stock Exchange. The first method is based on the principle of cointegration between stock prices and their fundamental value proposed by Campbell and Shiller (1987). Our results indicate that although stock prices diverge away from their fundamental value proxied by dividends or earnings, there exists an error correction mechanism which adjusts stock prices to revert back to their fundamental value. The second method consisted in estimating the model of Chiang, Liu and Okunev (1995) where the stock price is modeled as a mean reverting Ornstein Uhlenbeck process towards the fundamental value. We find evidence in favor of the mean reversion hypothesis especially for one and five year investment horizons. Evidence of mean reversion supports the predictability of stock returns by the dividend to price and the price to earnings ratios. Our results indicate that both the ratios have a good forecasting power for multiperiod returns when used separately. This result is confirmed when we use the forecasting model developed by the Chiang et al. (1995).

\section{Acknowledgements}

The authors wish to thank Chafai Cheker and two anonymous referees for their helpful comments and suggestions.

\section{References}

Akarim, Y. D., \& Sevim, S. (2013). The impact of mean reversion model on portfolio investment strategies-Empirical evidence from emerging markets. Economic Modelling, 31, 453-459. http://dx.doi.org/10.1016/j.econmod.2012.11.028 
Bachelier, L. (1900). Théorie de la speculation. Paris: Gauthier Villars.

Bali, T. G., Demirtas, K. O., \& Levy, H. (2008). Nonlinear mean reversion in stock prices. Journal of Banking and Finance, 32, 762-782. http://dx.doi.org/10.1016/j.jbankfin.2007.05.013

Balvers, R., Wu, Y., \& Gilliland, E. (2000). Mean Reversion across National Stock Markets and Parametric $\begin{array}{lllll}\text { Contrarian Investment strategies. Journal of Finance, 55(2), 745-772. } & \text {. }\end{array}$ http://dx.doi.org/10.1111/0022-1082.00225

Basu, S. (1977). Investment Performance of Common Stocks in Relation to Their Price-Earnings Ratios: A Test of the Efficient Market Hypothesis. Journal of Finance, 3, 663-682. http://dx.doi.org/10.1111/j.1540-6261.1977.tb01979.x

Bohl, M. T., \& Siklos, P. L. (2004). The present value model of U.S. stock prices reduce: A new testing strategy and some evidence. The Quarterly Review of Economics and Finance, 44, 208-223. http://dx.doi.org/10.1016/S1062-9769(03)00044-9

Campbell, J. Y., \& Shiller, R. J. (1987). Cointegration and tests of present value models. Journal of Political Economy, 95(5), 1062-1088. http://dx.doi.org/10.1086/261502

Campbell, J. Y., \& Shiller, R. J. (1988). Stock prices, earnings, and expected dividends. Journal of Finance, 43(3), 661-676. http://dx.doi.org/10.1111/j.1540-6261.1988.tb04598.x

Campbell, J. Y., Lo, A. W., \& MacKinlay, C. (1997). The econometrics of financial markets. Princeton University Press.

Chen, M. H., Kim, W. G., \& Chen, C. Y. (2007). An investigation of the mean reversion of hospitality stock prices towards their fundamental values: The case of Taiwan. Hospitality Management, 26, 453-467.

Chiang, R., Liu, P., \& Okunev, J. (1995). Modelling mean reversion of asset prices towards their fundamental value. Journal of Banking and Finance, 19, 1327-1340. http://dx.doi.org/10.1016/0378-4266(94)00115-J

Coakley, J., \& Fuertes, A. M. (2006). Valuation ratios and price deviations from fundamentals. Journal of Banking and Finance, 30, 2325-2346.

Cochrane, J. (2001). Asset pricing. Princeton, U.S.A.: Princeton University Press.

De Bondt, W. F. M., \& Thaler, R. M. (1985). Does the Stock Market Overreact? Journal of Finance, 40(3), 793-805. http://dx.doi.org/10.1111/j.1540-6261.1985.tb05004.x

Dickey, D. A., \& Fuller, W. A. (1981). Likelihood ratio statistics for autoregressive time series with unit root. Econometrica, 49(4), 1057-1072.

Fama, E. F. (1965). The Behavior of Stock-Market Prices. Journal of Business, 38(1), 34-105. http://dx.doi.org/10.1086/294743

Fama, E. F. (1970). Efficient capital markets: A review of theory and empirical work. Journal of Finance, 25(2), 383-417. http://dx.doi.org/10.1111/j.1540-6261.1970.tb00518.x

Fama, E. F. (1991). Efficient capital markets: II. Journal of Finance, 46(5), 1575-1617. http://dx.doi.org/10.1111/j.1540-6261.1991.tb04636.x

Fama, E. F., \& French, K. (1988a). Permanent and temporary components of stock prices. Journal of Political Economy, 96(2), 246-273.

Fama, E. F., \& French, K. R. (1988b). Dividend yields and expected stock returns. Journal of Financial Economics, 22, 3-25. http://dx.doi.org/10.1016/0304-405X(88)90020-7

Jensen. (1978). Some anomalous evidence regarding market efficiency. Journal of Financial Economics, 6(2-3), 95-101. http://dx.doi.org/10.1016/0304405X(78)90025-9

Johansen, S. (1991). Estimation and Hypothesis Testing of Cointegration Vectors in Gaussian Vector Autoregressive Models. Econometrica, 59, 1551-1580.

Kahneman, D., \& Tversky, A. (1982). Intuitive Prediction: Biases and Corrective Procedures. Judgment under uncertainty: Heuristics and biases. Cambridge University Press.

Kanas, A. (2005). Nonlinearity in the stock price-dividend relation. Journal of International Money and Finance, 24, 583-606. http://dx.doi.org/10.1016/j.jimonfin.2005.03.003

Kapetanios, G., Shin, Y., \& Snell, A. (2006). Testing for cointegration in nonlinear STAR error-correction models. Econometric Theory, 22, 279-303. 
McMillan, D. G. (2007). Bubbles in the dividend-price ratio? Evidence from an asymmetric exponential smooth-transition model. Journal of Banking and Finance, 31, 787-804. http://dx.doi.org/10.1016/j.jbankfin.2006.02.006

McMillan, D. G. (2009). Revisiting dividend yield dynamics and returns predictability: Evidence from a time-varying ESTR model. The Quarterly Review of Economics and Finance, 49, 870-883. http://dx.doi.org/10.2469/dig.v40.n1.16

McMillan, D. G., \& Speight, A. E. H. (2006). Non-linear long horizon returns predictability: Evidence form six south-east Asian markets. Asia-Pacific Financial Markets, 13, 95-111. http://hdl.handle.net/10.1007/s10690-007-9036-y

Nasseh, A., \& Strauss, J. (2004). Stock prices and the dividend discount model: did their relation break down in the 1990s? The Quarterly Review of Economics and Finance, 44, 191-207. http://dx.doi.org/10.1016/j.qref.2003.09.001

Osterwald-Lenum, M. (1992). A Note with Quantiles of the Asymptotic Distribution of the Maximum Likelihood Cointegration Rank Test Statistics. Oxford Bulletin of Economics and Statistics, 54, 461-472. http://dx.doi.org/10.1111/j.1468-0084.1992.tb00013.x

Park, C. (2010). When does the dividend-price ratio predict stock returns? Journal of Empirical Finance, 17, 81-101. http://dx.doi.org/10.1016/j.jempfin.2009.10.002

Phillips, P. C. B., \& Perron, P. (1988). Testing for a Unit Root in Time Series Regression. Biometrika, 75, 335-346.

Shiller, R. J. (1981). Do stock prices move too much to be justified by subsequent changes in dividends. The American Economic Review, 71(3), 421-436. http://dx.doi.org/10.3386/w0456

Summers, L. H. (1986). Does stock market rationally reflect fundamental values? Journal of Finance, 41(3), 591-601. http://dx.doi.org/10.1111/j.1540-6261.1986.tb04519.x

\section{Copyrights}

Copyright for this article is retained by the author(s), with first publication rights granted to the journal.

This is an open-access article distributed under the terms and conditions of the Creative Commons Attribution license (http://creativecommons.org/licenses/by/3.0/). 